\title{
Global effort is launched to create taxonomic map of living organisms
}

San Francisco. Three scientific societies have joined together to urge the United States to take the leading role in launching an international project, estimated to cost $\$ 3$ billion a year, systematically to chart all the world's plants, animals and other living organisms.

Such a programme, they claim - which has been given the title Systematics Agenda 2000 - would effectively extend the proposed US National Biological Survey into a global enterprise.

Announcing details of the proposed initiative during the annual meeting of the American Association for the Advancement of Science in San Francisco last week, the biologists responsible for it said that the project would take 25 years to complete.

It would also require international commitment to a sixfold increase in the $\$ 500$ million being spent each year - most of it in the United States - on collecting and classifying species. But they said that at the present rate of progress, a decent inventory of the world's species will take 150 years to collate, and that pressures from human activities are now so great that the inventory must be completed much more quickly.

Systematics Agenda 2000 is being backed by the American Society of Plant Taxonomists, the Society of Systematic Biologists and the Willi Hennig Society, and has been put together with financial support from the

National Science Foundation.

Justifying its ambitious scope, Peter Raven, director of the Missouri Botanical Garden in St Louis, claims that the world will not thrive by building microchips, automobiles or the information superhighway. "It will succeed only if we manage microorganisms properly," says Raven.

The programme would have three main research elements. These would focus on the discovery of unknown species, on developing an improved understanding of the relationships between them and on developing computer networks and databases to store information about biodiversity.

Most of the work would

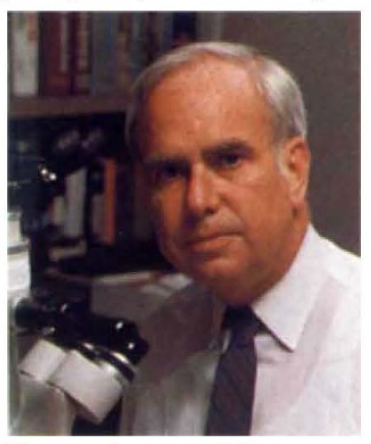

Raven: 'we need to manage properly'.

even the poorest countries could benefit from investing money in preserving biodiversity. For example, he says, their ability to negotiate with international corporations keen to exploit local species will benefit greatly from "even two or three people" working on the topic. The proposal cites projects such those being conducted by Conabio in Mexico and the Instituto Nacional de Biodiversidad (INBio) in Costa Rica, as well as the US National Biological Survey, as models for a systematic approach to biological diversity.

Another biologist who has been involved in drawing up the proposed programme, David Wake of the University of California at Berkeley,

be carried out in developing

countries, which are thought to contain the widest range of biological species, and the programme proposals claim that various United Nations and other international agencies, could play a role.

But the plan remains vague about how these efforts should be funded. Its authors emphasize that they are proposing an international scientific collaboration, not an aid programme. But Raven, who is a member of the programme's steering group, argues that

\section{US Congressmen in bid for medical funds}

Washington. In an attempt to emphasize that support for medical research must go hand in hand with healthcare reform, two US Senators this week unveiled a legislative proposal to create a national fund for medical research within the US Treasury.

If enacted, the fund would be expected to provide an estimated US\$5 to $\$ 6$ billion annually in additional support for the US National Institutes of Health (NIH), at a time when discretionary spending within the government has been frozen for the next four years.

The fund would be financed from two sources. One would be a one per cent setaside from all monthly health insurance premiums; the other a provision enabling the public to make voluntary contributions by marking a box on their annual federal income-tax returns.

Money allocated through the fund would not be earmarked for specific areas of research. Rather it would be distributed to $\mathrm{NIH}$ institutes and centres in proportion to the amount which each receives through the annual appropriations process. To ensure that the fund supplements, rather than supplants, existing NIH appropriations, money would be made available through it in any one year only if Congress matches or exceeds the previous year's appropriation.

The proposal, which has bipartisan backing in the Senate, is being sponsored by Senators Tom Harkin (Democrat, Iowa), Mark Hatfield (Republican, Oregon), Nancy Kassebaum (Republican, Kansas) and Edward Kennedy (Democrat, Massachusetts). Similar legislation is expected to be introduced shortly in the House by Bill Coyne (Democrat, Pennsylvania).

"It is past time to expand the debate on healthcare," Harkin said on Monday. Until the importance of medical research receivesserious emphasis, "every other step we take on healthcare reform is just like rearranging deckchairs on the Titanic."

A recent Louis Harris poll of more than 1,200 adults found that more than 70 per cent of those surveyed would be willing to pay US\$1 more per week in health insurance premiums if they knew it would go towards medical research. Diane Gershon says the main need is for more information and knowledge. "When we spend money, we should do it in an intelligent way," says Wake, whose own interest is in the taxonomy of toads. He claims that governments only act to conserve "cuddly" species, such as the spotted owl, while those of greater scientific importance are allowed to become extinct.

Joel Cracraft of the American Museum of Natural History in New York, the chairman of the group that prepared the Agenda proposals, acknowledges that their publication is merely the first step in a long process of building international support.

The process will continue with symposia being planned in London and Paris in the spring, and another by the United Nations Educational, Scientific and Cultural Organisation (UNESCO) later in the year. The London meeting takes place at the Royal Society on 12 April, to be followed on 15 April by a meeting organized by the Société Française de Systematique in Paris.

Key members of the planning group will be attending the European meetings. "The idea is to publicise this initiative and advance the agenda," says Michael Claridge, professor of zoology at the University of Wales in Cardiff and one of the speakers at the London symposium. "We all agree is a marvellous idea and a very ambitious one."

But the backers of Systematics Agenda 2000 acknowledge that it may be difficult to find support outside the United States, where public awareness of the biodiversity issue is already high. Raven claims that many European countries are holding back from making any significant financial commitments, while Japan "is almost totally insensitive to biodiversity issues".

Colin Macilwain 